Roel Konijnendijk*

\title{
Risk, chance and danger in Classical Greek writing on battle
}

https://doi.org/10.1515/jah-2020-0006

\begin{abstract}
This article highlights two aspects of the language used in Classical Greek literary sources to discuss pitched battle. First, the sources regularly use unqualified forms of the verb kinduneuein, "to take a risk," when they mean fighting a battle. They do so especially in contexts of deliberation about the need to fight. Second, they often describe the outcome of major engagements in terms of luck, fate, and random chance, at the explicit expense of human agency. Taken together, these aspects of writing on war suggest that pitched battle was seen as an inherently risky course of action with unacceptably unpredictable results, which was therefore best avoided. Several examples show that the decision to fight was indeed evaluated in such terms. This practice casts further doubt on the traditional view that Greek armies engaged in pitched battles as a matter of principle.
\end{abstract}

Keywords: Greek warfare, risk, pitched battle, military thought, historiography

There is an unresolved tension in the way modern scholars assess the place of pitched battle in the Greek way of war. On the one hand, many still subscribe to the traditional view that the Greeks perceived pitched battle on level ground as "the preferred, most heroic, and best method of deciding conflicts." ${ }^{1}$ On the other hand, it is widely acknowledged that Greek authors advocate the avoidance of such battles and praise the use of ambush, deception and trickery. ${ }^{2}$ There was an

1 Hanson (2000), 219. For more recent expressions of this view, see Bouvier (2006); Friend (2007); Hanson (2013), 258-259; Millender (2016), 163; Pritchard (2019), 193-194.

2 See especially Wheeler (1988); Krentz (2000); Sheldon (2012).

Note: This article was made possible by funding from the EU Horizon2020 research and innovation programme under the Marie Skłodowska-Curie grant agreement No 794093. It offers a closer look at one part of a wider argument about Greek attitudes to pitched battle (Konijnendijk 2021).

*Corresponding author: Roel Konijnendijk, Institute for History, Leiden University, Doelensteeg 16, 2311 VL Leiden, The Netherlands, E-Mail: r.b.konijnendijk@hum.leidenuniv.nl 
obvious pragmatic case for this cynical alternative: it achieved greater results at less risk than fighting in the open.

The emphasis that recent scholars have placed on the volatility of hoplite battle suggests how forceful this argument may have been to the Greeks themselves. In set-piece engagements, even a local loss of nerve could rapidly develop into a general collapse, exposing the entire army to the horrors of encirclement or pursuit. ${ }^{3}$ There were many potential causes of such a calamity, from disorder in the ranks ${ }^{4}$ to the appearance of particularly daunting opponents ${ }^{5}$ or the death of the general. ${ }^{6}$ Confusion and sensory deprivation could cause debilitating panic fear. ${ }^{7}$ Even bad weather could cause battle lines to waver. ${ }^{8}$ Several of these causes of catastrophe were not just common but endemic to hoplite battle. ${ }^{9}$

With such terrifying forces at play, the outcome of an engagement was never certain, and the price of defeat could be staggering. Sudden, unexpected reverses could turn even an apparent victory into a disaster in the blink of an eye. ${ }^{10}$ To put it another way, chance seems to have played an important role in major engagements, and the consequences of its interference with best laid plans could be decisive. The degree of control that commanders could exercise over the outcome of open battle was correspondingly limited. At the same time, these commanders, their men, and their communities at home faced serious consequences if a battle did not go their way. All this suggests that the Greeks should have preferred to avoid the gamble of a battle in the open if more dependable options were available.

Two possible indications of such an attitude in Classical Greek texts on war have so far escaped the attention of scholars. First, these texts regularly use forms

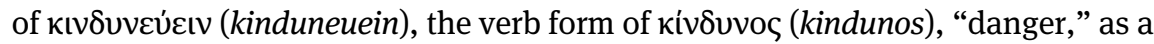
direct synonym for fighting a battle. Second, they use various expressions to un-

3 Culham (1989), 199; Hanson (1989), 177-183; Lazenby (1991); Echeverría (2011), 70-72; Van Wees (2011), 71-76; Millender (2016), 166-167; Konijnendijk (2018), 178-188.

4 Krentz (1985), 58-59; Crowley (2012), 49-53. Xen. Oec. 8.4 emphatically describes an army in disorder as "the easiest prey to enemies, the most inglorious sight to friends, the most useless."

5 Millender (2016), 189-190; Konijnendijk (2018), 102-103; (2019).

6 Plut. Pel. 2.1-4-although perhaps the most prominent example in Greek history is that of Mardonios at Plataiai.

7 Hanson (1989), 102-103; Christ (2006), 100-102.

8 Thuc. 6.70.1; Plut. Tim. 28.1-5; see Corvisier (2018).

9 Thuc. tells us categorically that advancing formations lose their order (5.70), that men in combat lose awareness of their surroundings (7.44.1), and that large armies are often seized by groundless panics $(3.30 .4,4.125 .1,7.80 .3)$. Modern scholars stress how often Greek commanders would die in battle: Hanson (1989), 111-115; Lazenby (1991), 98; Wheeler (1991), 146-151; Debidour (2002), 44; Lendon (2005), 89.

10 Hdt. 9.69.2; Thuc. 4.96.5-6; Xen. Hell. 4.4.11-12; Diod. 15.72.3; Plut. Phoc. 13.2. 
derline that the course of such engagements could be seen as a matter of chance or fate. Their use of the language of risk and random chance in this context helps to characterise the acceptance of battle in the open-and especially hand-to-hand combat-as a reckless act with unforeseeable consequences. It implicitly advocates safer courses of action. As such, in its small way, it further discredits the notion that the Greeks saw pitched battle as a standard approach to war, let alone one that was morally ordained. In this article I will illustrate what these elements of writing on battle look like, and what they may imply about the Classical Greek perception of battle in the open.

I begin with kinduneuein. This verb seems to have been unknown to Homer and the early poets; it is a word of the Classical period and, at least until Euripides, of prose. It and its variants have no direct equivalent in English and can be variously translated in context, but its general meaning is clear: to do something daring, "make a venture, take a risk" (LSJ). The verb's many grammatical permutations all express the notion of doing something dangerous, risking a particular consequence, or putting something in danger. The constituent elements of chance (the unpredictability of the outcome) and risk (the possibility of injury or loss) are as tightly interwoven in the uses of the word as they are in military action.

The connection of this verb to war is not surprising, and at first sight it may not seem significant. After all, the word can be used for a whole range of activities in which people may come to harm, as demonstrated by Plato's phrase "kinduneuontas on the sea and in war" (Charm. 173b). Even where it is clear from the context that the verb refers to risking one's life in armed conflict, the reference can be generic, such as in Xenophon's report that Kyros the Younger would reward any soldier who showed himself willing to kinduneuein (An. 1.9.14-15), or Xenophon's own claim that he had "worked hard and kinduneusanta" alongside his men throughout their march. ${ }^{11}$ Like the noun kindunos, ${ }^{12}$ the verb could be used to indicate the perils of war without getting into specifics. ${ }^{13}$ Orators use it in this sense when they present kinduneuein for the polis as the duty of a good citizen. ${ }^{14}$

11 Xen. An. 7.6.36. He regularly uses some form of the phrase "work hard and run risks" to sum up the business of the professional soldier (see also An. 1.4.14, 7.3.31; Hell. 5.1.16; Hiero 10.6; Cyr. 1.5.12). Consequently, he believed that a good soldier should be philokindunos ("fond of danger:" An. 2.6.7; Cyr. 2.1.22).

12 For example, Hdt. 7.10d.1; 8.65.3; Eur. Heracl. 503-504; Thuc. 2.39.1; Andoc. 1.11; Aeschin. 3.148; Dem. 18.220; Arist. Pol.1333b.20-21.

13 Hippoc. Aer. 16.35-40 demonstrates this usage when he says that the free peoples of Asia are particularly warlike because the kindunous that they kinduneuousi benefit them and no one else. 14 For example, Thuc. 2.39.4, 2.61.1; Andoc. 4.1; Lys. 2.63, and the tautological pollous kindunous kekinduneuka ("I have risked many risks") of the speaker of Lys. 3.47. 
But its meaning is not always so broad. When Demosthenes describes Artaxerxes kinduneusanta for his throne against Klearchos and Kyros (15.24), we know that the reference must be to the singular and decisive battle of Kounaxa. When he swears by the ancestors who prokinduneusantas at Marathon (18.208), we have a similarly specific context for the dangers they faced. ${ }^{15}$ In these instances kinduneuein does not refer to general risk-taking but to the specific act of fighting a battle. We find this usage across different kinds of text commenting on war. For example, Aischines boasts that he had ekinduneusa with the Athenian picked troops at Tamynai (2.169); in his mock funeral oration, Plato asserts that the Athenian example at Marathon encouraged other Greeks to diakinduneuein in later battles against the Persians. ${ }^{16}$ Xenophon's Sokrates argues that a cavalry force imbued with love of honour will surpass others in "readiness to kinduneuein with the enemy" (Mem. 3.3.14). But Xenophon also urges caution, since the Athenian cavalry is too weak to "diakinduneuein in the open" without support (Eq. Mag. 7.7). Such passages demonstrate that "taking a risk" or "going into danger" could be understood as another word for fighting-or, more specifically, for taking one's chances in open battle.

This sense of the verb is particularly common to the Greek historians. Their works all contain examples of the unadorned use of kinduneuein and its variants as a direct equivalent to more specifically warlike words like machein ("to fight") or paratassein ("to deploy for battle"). ${ }^{17} \mathrm{~A}$ basic word search reveals that this is particularly true for Thucydides, whose work contains three times as many instances of kinduneuein (in all its meanings) as Herodotos' Histories and more than five times as many as Xenophon's Hellenika. But the use of this verb in this particular sense across many authors shows that it is not merely a symptom of Thucydides' well-known concern with risk and chance in war (more on which below). I will cite a number of examples here to illustrate what the use of forms of kinduneuō in the specific sense of going into battle looks like across the Classical Greek historians.

According to Herodotos (4.11.2), when the Kimmerians debated whether to resist the invading Skythians, the common people argued that there was no sense

15 Other authors also used this form of the verb, with prefix, to stress that the Marathon-fighters were the first of the mainland Greeks to stand up to the Persians: see for example Thuc. 1.73.4; Isoc. 4.75 .

$16 \mathrm{Pl}$. Menex. 240e; with this prefix the verb might be translated "endure danger" or (with LSJ) "run all risks." Elsewhere, Pl. Rep. 556c-d refers to troops in battle as being en tois kindunois, "in the dangers."

17 Pritchett's (1974), 147-155 chapter on the challenge to battle contains examples of each of these terms to mark an engagement, but he did not discuss their literal meaning. 
in kinduneuein for land they could simply abandon. ${ }^{18}$ The Greek allies at Salamis were divided over whether they should withdraw and kinduneuein for the Peloponnese, or stay and fight where they were (Hdt. 8.74.2). Thucydides' Archidamos gambled that the devastation of the land around Acharnai would make the Acharnians less eager to kinduneuein for that of other Athenians (2.20.4). The Macedonian cavalry under Perdikkas stopped harassing the Thracian invaders "thinking they were not strong enough to kinduneuein against so many" (Thuc. 2.100.5). The Athenian generals deliberating on whether to fight at Megara in 424 assumed their enemies would be more willing to kinduneuein than they were themselves, since each Peloponnesian state risked only a fraction of its citizens. ${ }^{19}$ The battle of Delion happened because Pagondas persuaded the Boiotians that they should kinduneusai instead of disbanding the army (Thuc. 4.91). At Amphipolis, Brasidas had to assuage the concern of his troops about his plan to "kinduneuein with only a few instead of everyone" (Thuc. 5.9.2). After one defeat and one aborted engagement, the Syracusan generals were no longer willing to diakinduneuein against the Athenians with their whole levy (Thuc. 6.99.2). Later, low morale and dwindling supplies made Nikias keen to "diakinduneuein as soon as possible" (Thuc. 7.60.5). According to Xenophon (Hell. 5.4.40), when Agesilaos invaded Boiotia in 378 , the Thebans took up position on a particular hill because they considered it a suitable place for diakinduneuein. In the aftermath of the battle of Leuktra, Iason of Pherai tried to persuade the Thebans that it was not the right time to diakinduneusai and destroy the Spartans for good (Hell. 6.4.22). We still find the verb used in the same sense in Polybios (13.3.5), who claimed that the Greeks of times past would announce to their enemies "when they proposed to diakinduneuein."

These passages leave no room for broad interpretations. When they speak of going into danger, they mean going into battle. The verb did not require any elaboration to be understood as such. Indeed, its usage in these examples is clearly distinct from cases where it carries an object to show what is being put at risk. Elsewhere, Thucydides' speakers may urge the Athenians "not to kinduneuontas the city" (2.65.7) or not to "kinduneuein what is already yours" (6.9.3), in which case we must read the verb in the sense of "put X at risk" or "expose X to danger." But in the passages above, the verb does not act on anything. The warriors in-

18 Both here and in the debate between the Athenian generals before Marathon (6.109.2), Hdt. shares his opinion that it would be better to fight. This should probably be read as an indirect review of Perikles' strategy in the Peloponnesian War.

19 Thuc. 4.73.4 with Hornblower (1996), 243-244. The passage is rich with kindunos: it describes a Peloponnesian force unwilling to provoke machēs kai kindunou ("battle and danger," 4.73.2) while its Athenian opponents "reckoned that the kindunon was not equal" if it came to a fight (4.73.4). For the phrase "the kindunos is not equal," see also Xen. Hell. 7.1.7. 
volved were not risking a particular outcome, but just "risking," which meant engaging the enemy. Examples of this usage in the historians can be multiplied. ${ }^{20}$

The passages above share another salient feature. Each of these episodes involves thoughts on battles to come. Forms of kinduneuein occur many times elsewhere in the historians, but its use as a synonym for fighting a battle is nearly exclusive to contexts in which individuals or groups are looking ahead and assessing a (possible) future clash. The only exceptions I have been able to find are a few speakers praising the generation that kinduneusai against the Persians (Thuc. 1.73.2, 1.74.2, 6.83.2). It seems, then, that the historians regarded this verb as especially suitable to describe potential engagements, often as part of a public debate or private deliberation over whether to have one or not. In other words, battle was reduced to its risks and dangers specifically at times when the question was asked, "should we fight?" This usage suggests that the perceived risks of open battle helped shape Greek attitudes to it and played a role in military planning.

The use of kinduneuein as a synonym for doing battle is not the only indication of such a mentality. Several passages in the literary record show that the outcome of pitched battles was thought to be determined to a large extent by luck or the influence of unforeseeable factors. These passages demonstrate even more clearly that the decision to commit to such engagements could be interpreted as reckless, regardless of the moral or strategic stakes.

Again, these references to luck and randomness are particularly common in Thucydides. It is no novel insight that this historian stresses the impact of chance on the outcome of wars as a whole, and that his characters do so specifically to warn audiences and discourage action. He makes his speakers declare that it is impossible to calculate the "freaks of chance" that occur in war (1.84.3), that "war is driven by its tychai" (chance, random events: 4.18.4) and that "as it lengthens, it becomes mostly a matter of chance" (1.78.2). Those who consider going to war must beware of its paralogoi (accidents, unexpected things: 1.78 .1 ) and its astathmètoi (uncertainties: 4.62.4); even the mighty need good fortune to prevail (6.23.3). Gomme already considered this "a commonplace” in Thucydides' work. ${ }^{21}$ A substantial body of scholarship is devoted to the role of chance and uncertainty in Thucydides' analysis of political and military decision-making and in his understanding of historical causality. ${ }^{22}$

20 See for instance Hdt. 9.100.2; Thuc. 1.142.8, 3.5.2, 4.108.6, 6.78.1, 7.47.3, 8.27.2, 8.79.2; Xen. An. 6.3.13; Hell. 2.4.20. Polybios contains many additional examples, which I will leave out of consideration here.

21 Gomme (1950), 245.

22 See for instance Stahl (1966); Herter (1968); Edmunds (1975); Luginbill (1999), 53-59; Ober (2012); Hau (2016), 202-207. For case studies of the importance of chance in Thuc.'s narrative of the 
Unsurprisingly, when we zoom in from the bigger picture of war to specific moments of violent action, we find that Thucydides makes consistent appeals to the role of chance in that narrower context, too. He has Nikias exhort his despondent army before the decisive engagement at Syracuse to "remember the accidents of war and hope that fortune (tēs tychēs) can also be on our side" (7.61.3). The Melians justify their resistance to the Athenians in part by asserting that "the chances of war" sometimes favour the weak. ${ }^{23}$ Similarly, in his attempt to excuse the rebel Mytileneans, Diodotos notes that the very randomness of tyche can persuade people and states to kinduneuein despite their lack of means (3.45.6). To prove his political and military acumen to the Athenian assembly, Alkibiades boasts that his machinations in the Peloponnese in 420-418 had involved "no great risk or expense to you," but had "forced the Spartans to stake everything on a single day's fighting at Mantineia." 24 Each of these statements imply a belief that individual engagements were as greatly affected by tyche- - "the degree by which the outcome differs from the expectation" 25 -as war in its totality.

But Thucydides is neither the first nor the only author to express this belief, and other sources throughout the Classical period make the point explicit. In Aischylos' Seven Against Thebes, produced in 467, Eteokles carefully selects Melanippos as his champion against Tydeus, but accepts that ultimately, "Ares will decide the matter with a roll of the dice" (414). Euripides' Amphitryon prefers archers and ambushes over hoplites and hand-to-hand combat, because "in battle, this is the wisest by far: to do harm to the enemy while keeping yourself safe, and not to depend on tychē" (Her. 201-203; the play dates to c. 416). In his Panegyrikos of 380, Isokrates claims that the Athenians fought hard at Artemision to prove that they had won their earlier victory at Marathon "by their excellence and not through tyche" (4.91)-suggesting that a single victory might be written off as a fluke, and further success was needed to show that there was more than luck on the Athenian side. In the same author's speech for Archidamos, written around

Peloponnesian War, see Monoson and Loriaux (1998), 288-290; Heilke (2004), 124-127. Culham (1989), 191-192 notes that chance was of similar concern to Polybios; this is reflected in his frequent use of kinduneuō and its variants.

23 Thuc. 5.102; for the psychology behind their apparently reckless decision, see Orwin (1994), 103-109; Ober (2012), 5-7.

24 Thuc. 6.16.6; compare 8.79.2; Diod. 15.65.5; Plut. Per. 33.4. This view of pitched battle also occurs in Aeschin. 3.148 who claims that Philip II preferred a peace treaty over battle at Chaironeia because "he was not unaware, since he was no fool, that he was about to contend in one small part of a day for all the good things he possessed.” Aeschin.'s phrasing may have inspired Plut.'s comment that Philip at Chaironeia "was forced to face kindunon in one small part of a day for his hegemony and his life" (Dem. 20.3).

25 Edmunds (1975), 207. 
366 , he makes the Spartan prince argue that the decisions of citizens in assembly are better proof of their courage than the outcome of battles, since "the greatest part of what happens in battle is due to tyche" (6.92).

Such passages demonstrate a widespread belief that even the best men could be reduced to mere pawns of inscrutable forces. Herodotos' wise counsellor Artabanos urges Xerxes to remember that even the most careful plans can be ruined by tēs tychēs, and that the gods in their envy will often help small armies defeat mighty ones (7.10d-e). Similarly, Iason of Pherai warned the Thebans against attempting to crush the remaining Spartans in a second battle after Leuktra, since the disaster had humbled them, and "the god, it seems, often takes pleasure in making the small great, and the great small” (Xen. Hell. 6.4.23). On the Athenian victory at Tamynai, mentioned above, the eyewitness Aischines commented that "first, some god saved the army, and then your soldiers, both infantry and cavalry, became good men" (3.88). Of course, such appeals to a higher power could also be used to clear warriors of blame for their defeat, as Demosthenes tried to do in his funeral oration after the calamity at Chaironeia:

"If someone were to ask those deployed against us whether they thought they had won by their own excellence, or by a startling and cruel tyche and by the skill and daring of their own commander, not one of them would be so shameless or audacious as to claim credit for what happened. Indeed, in those things where the deity, the master of all, has determined the outcome as it saw fit, we must acquit all others of anything bad, since they are only human." (60.21)

This is not to say that the Greeks threw up their hands and ascribed the outcome of every battle to the gods. Such explanations are understandably rare in the literature; they would leave little for the author to describe or for the reader to learn. Instead, Greek authors built meticulous causal frameworks to explain victory and defeat, which have been the subject of some excellent modern studies. ${ }^{26}$ Their accounts typically allowed for a range of human and environmental factors. But as the passages above make clear, they recognised that not all these factors were known or knowable in advance. They were all subject to a higher, more capricious force. In hindsight, whether it was human agency, tyche, or divine intervention that had proved decisive could be a matter of debate. Conversely, it was understood that no amount of preparation, superiority, or genius could guarantee the outcome of a battle.

26 Culham (1989); Corvisier (2013); Lendon (2017), 62-64; Foster (2018); Pelling (2019), 163-173; Millington (forthcoming). 
This sense of the limits of human influence on the course of events led Xenophon to urge military leaders to consult the gods at every turn, to attain as much knowledge and control over their situation as they could. ${ }^{27}$ His insistence on this point reveals how much this veteran commander believed warriors to be subject to the whims of the unseen. He claims that the "most important lesson of all" that Cambyses imparted to his son Cyrus was to "never kinduneuseis either by yourself or with the army if the sacrifices and omens are against it," since human beings can only guess which path will lead to success (Cyr. 1.6.44). He has a simple message for readers who doubt the value of such advice: "if you kinduneuei often, you will understand" (Eq. Mag. 9.8).

Did this perception of battle affect military decisions, or at least the representation of those decisions in the surviving evidence? I believe that it did. There are a few notable examples where the role of random chance in the outcome of battles seems to have been a major element in the evaluation of the decision to fight one.

One such case is the prelude to the encounter of Athenians and Peloponnesians at Megara, cited above. When the Athenian army arrived and infiltrated the long walls between Megara and Nisaia, conspirators in Megara tried to persuade their fellow citizens to sally and fight; the plan was for the Athenians to pour in as soon as the gates were opened. But their opponents in the city rejected the proposal, arguing that they "had never before dared such a thing, even when they were much stronger;" they must not march out and "drag the city into obvious kindunon" (Thuc. 4.68.6). The fact that they were trying to stop the sally because they had found out about the conspiracy makes no difference here, since they were trying to hide their knowledge of the plot; they could only use arguments that would appear valid in and of themselves. As they insisted, "their counsel was best." In the end, a public appeal to the risks of fighting a battle-and to a consistent risk-averse policy-was enough to thwart the plans of the conspirators.

While his Argive allies were apparently upset with the Athenian commander Phrynichos for his decision to withdraw from Miletos in 412, Thucydides praised him for it, noting that he refused to be goaded into "diakinduneusein senselessly" without due preparation and potentially exposing Athens to "the greatest kindunōi” if he lost (8.27.2-3). If it is right to characterise Thucydides as an author particularly concerned with risk and chance in war, it is not surprising that he would favour Phrynichos' cautious and level-headed assessment. At the same time, Lysias argues that showing a consistent willingness to fight could persuade enemies to turn their attentions to easier targets: when the Spartans realised that the Argives and Mantineians would always march out to meet them in battle, "they

27 Agrimonti (2016). 
thought the kindunos was not worth it" and ceased their invasions (34.8). He adds that this was due to their awareness of how much they had to lose: "the more they prospered, the less they desired to kinduneuein."

In 409 the Athenians sent an army into the Megarid to recapture Nisaia. This army happened upon a force of Megarians and Spartans at a place called the Horns. The Athenian generals decided to engage the enemy and won a surprise victory - the first time they had defeated Spartans on land since Sphakteria (Hell. Oxy. 1.1; Diod. 13.65.2). Yet, even though the Athenians were delighted with the victory, they did not receive their generals as heroes (Hell. Oxy. 1.2, trans. McKechnie and Kern): "But the Athenians, having found out about the battle, were angry with the generals and took a hostile attitude, supposing that they had undertaken the kindunon rashly and played dice with the whole city at stake." It is hard to imagine a more forceful expression of the belief that chance played an unacceptably large role in the outcome of battles. For the simple act of fighting-and winning!-a minor engagement in the open, the Athenians accused their generals of gambling with the lives of citizens and the defensive capacity of the state. They could not celebrate men who had so recklessly exposed their troops and their community to the terrible risks of pitched battle.

These passages reveal a much more measured and apprehensive view of pitched battle than the one traditionally assumed by modern scholars. Massed engagements, especially between hoplites fighting at close quarters, were accumulations of largely isolated and uncontrollable events-the sum of thousands of individual struggles between warriors and within warriors' minds. Keenly aware of the uncertainties and catastrophic potential of such engagements, Greek authors cast their discussions about fighting a battle in the vocabulary of risk and danger; they assessed its outcome in hindsight as the work of chance or fate. In some cases, they were prepared to accept reference to perceived risks as a sufficient reason to avoid a battle. In others, they censured generals for failing to appreciate the stakes and the limits of their own control. Similar allusions to the unpredictability of the outcome rarely occur in accounts of ambushes and surprise attacks. All this suggests that the Classical Greeks would not have accepted the gamble of battle in the open without careful deliberation. It lends support to the view that they would be open to any means-fair or not-to manage risk and improve the chances of victory.

Acknowledgment: I am grateful to Hans van Wees and Jason Crowley for their comments on earlier drafts; any remaining mistakes or omissions are my own. 


\section{Bibliography}

Agrimonti, S. "Xenophon's piety within the Hipparchikos." In The Religious Aspects of War in the Ancient Near East, Greece, and Rome, edited by K. Ulanowski, 194-205. Leiden: Brill, 2016.

Bouvier, D. "De la plane de Troie au champ de bataille hoplitique: la tradition d'une guerre sans ruse en Grèce ancienne." In Ruses, Secrets et Mensognes chez les Historiens Grecs et Latins, edited by H. Olivier, P. Giovannelli-Jouanna and F. Bérard, 27-50. Lyon: Université Jean Moulin Lyon 3, 2006.

Christ, M. The Bad Citizen in Classical Athens. Cambridge: Cambridge U. P., 2006.

Corvisier, J.-N. “Incompétences militaires et causes de l'échec en Grèce ancienne." REMA 6 (2013): 35-52.

Corvisier, J.-N. “Les phénomènes naturels: une cause d'échec dans la guerre antique?" HiMA 7 (2018): 3-12.

Crowley, J. The Psychology of the Athenian Hoplite. Cambridge: Cambridge U. P., 2012.

Culham P. "Chance, command, and chaos in ancient military engagements." World Futures 27 (1989): 191-205.

Debidour, M. Les Grecs et la Guerre, Ve-IVe Siècles: de la Guerre Rituelle à la Guerre Totale. Monaco: Du Rocher, 2002.

Echeverría, F. "Taktikè technè: the neglected element in Classical 'hoplite' battles." Ancient Society 41 (2011): 45-82.

Edmunds, L. Chance and Intelligence in Thucydides. Cambridge: Harvard U. P., 1975.

Foster, E. "Military defeat in fifth-century Athens: Thucydides and his audience." In Brill's Companion to Military Defeat in Ancient Mediterranean Society, edited by J. Clark and B. Turner, 99-122. Leiden: Brill, 2018.

Friend, J. "The notion of a fair fight in ancient Greece and in modern warfare." In Experiencing War, edited by M. Cosmopoulos, 95-121. Chicago: Ares, 2007.

Gomme, A. A Historical Commentary on Thucydides. Vol. I. Oxford: Oxford U. P., 1950.

Hanson, V. The Western Way of War. New York: Knopf, 1989.

Hanson, V. "Hoplite battle as Ancient Greek warfare: when, where, and why?" In War and Violence in Ancient Greece, edited by H. van Wees, 201-232. Swansea: Classical Press of Wales, 2000.

Hanson, V. "The hoplite narrative." In Men of Bronze, edited by D. Kagan and G. Viggiano, 256-275. Princeton: Princeton U. P., 2013.

Hau, L. Moral History from Herodotus to Diodorus Siculus. Edinburgh: Edinburgh U. P., 2016.

Heilke, T. "Realism, narrative, and happenstance: Thucydides' tale of Brasidas." American Political Science Review 98.1 (2004): 121-138.

Herter, H. "Freiheit und Gebundenheit des Staatsmannes bei Thukydides." In Thukydides, edited by H. Herter, 260-281. Darmstadt: Wissenschaftliche Buchgesellschaft, 1968.

Hornblower, S. A Commentary on Thucydides. Vol. II. Oxford: Oxford U. P., 1996.

Konijnendijk, R. Classical Greek Tactics: A Cultural History. Leiden: Brill, 2018.

Konijnendijk, R. "Commemoration through fear: the Spartan reputation as a weapon of war." In Commemorating War and War Dead, edited by M. Giangiulio, E. Franchi and G. Proietti, 257-269. Stuttgart: Franz Steiner, 2019.

Konijnendijk, R. “Playing dice for the polis: pitched battle in Greek military thought.” TAPA 151 (2021): forthcoming.

Krentz, P. “The nature of hoplite battle." CA 4 (1985): 50-61. 
Krentz, P. “Deception in Archaic and Classical Greek warfare." In War and Violence in Ancient Greece, edited by H. van Wees, 167-200. Swansea: Classical Press of Wales, 2000.

Lazenby, J. “The killing zone.” In Hoplites, edited by V. Hanson, 87-109. London: Routledge, 1991.

Lendon, J. Soldiers and Ghosts. New Haven: Yale U. P., 2005.

Lendon, J. "Battle descriptions in the ancient historians, part I: structure, array, and fighting." G\&R 64 (2017): 39-64.

Luginbill, R. Thucydides on War and National Character. Boulder: Westview, 1999.

Millender, E. "The Greek battlefield: Classical Sparta and the spectacle of hoplite warfare." In The Topography of Violence in the Greco-Roman World, edited by W. Riess and G. Fagan, 162-194. Ann Arbor: University of Michigan, 2016.

Millington, A. "Worshipping violence." In Beyond the Phalanx, edited by R. Konijnendijk, C. Kucewicz and M. Lloyd (forthcoming).

Monoson, S. and M. Loriaux, "The illusion of power and the disruption of moral norms: Thucydides’ critique of Periclean policy.” American Political Science Review 92 (1998): 285-297.

Ober, J. “Thucydides as prospect theorist.” Princeton/Standford Working Paper (2012): https:// ssrn.com/abstract=1431169

Orwin, C. The Humanity of Thucydides. Princeton: Princeton U. P., 1994.

Pelling, C. Herodotus and the Question Why. Austin: University of Texas, 2019.

Pritchard, D. Athenian Democracy at War. Cambridge: Cambridge U. P., 2019.

Pritchett, W. The Greek State at War. Vol. II. Berkeley: University of California, 1974.

Sheldon, R. Ambush: Surprise Attack in Ancient Greek Warfare. Barnsley: Pen \& Sword, 2012.

Stahl, H.-P. Thukydides. Munich: Beck, 1966.

Van Wees, H. "Defeat and destruction: the ethics of ancient Greek warfare." In Böser Krieg, edited by S. Tausend and M. Linder, 69-110. Graz: Gräzer Universitätsverlag, 2011.

Wheeler, E. Stratagem and the Vocabulary of Military Trickery. Leiden: Brill, 1988.

Wheeler, E. “The general as hoplite.” In Hoplites, edited by V. Hanson, 121-170. London: Routledge, 1991. 